\begin{tabular}{c} 
JOURNAL OF APPLIED SMART ELECTRICAL \\
NETWORK AND SYSTEMS (JASENS) \\
\cline { 2 - 3 }
\end{tabular}

\title{
Pembangkit Energi Listrik Hybrid Mini Menggunakan Turbin Angin Sumbu Vertikal Savonius Sebagai Sumber Energi Alternatif
}

\author{
Edo Triyandi ${ }^{1}$, Pola Risma ${ }^{2}$, RD. Kusumanto ${ }^{3}$, Tresna Dewi ${ }^{4}$, Yurni Oktarini ${ }^{5}$ \\ 1,2,3,4,5 Jurusan Teknik Elektro, Politeknik Negeri Sriwijaya \\ 1edotriyandi@gmail.com,2polarisma@polsri.ac.id,3manto_6611@yahoo.co.id, \\ tresna_dewi@polsri.ac.id, ${ }^{5}$ yurni_oktarina@polsri.ac.id
}

\begin{abstract}
Hybrid system is the concept of combining two or more different energy sources to meet the needs of the existing electrical load, so this is expected to overcome energy use if the supply of other electrical energy is problematic. One example is the merging of solar energy and wind energy. The advantages of this hybrid generator are that it is non-polluting, abundant, never runs out and can be used directly or indirectly and is energy for all time. In the wind energy generator section, the type of Savonius vertical axis wind turbine is used, where this turbine is very suitable for use in low-speed wind types such as the one in the city of Palembang using the MY-1016 generator with an output power of 350 Watt. The mini hybrid electric energy generation system uses a savonius vertical axis wind turbine as an alternative energy source consisting of several components, including: Savonius vertical axis wind turbine, MY-1016 Generator, Controller, Internet of Things (IOT), Anemometer sensor, INA219 current sensor, Energy storage system (battery, pump storage), and 1500-Watt Inverter.
\end{abstract}

Keywords: savonius vertical axis wind turbine, generator MY-1016, anemometer sensor, INA219 current sensor, Internet Of Things (IOT), battery, 1500 Watt Inverter.

\begin{abstract}
Abstrak
Sistem Hybrid merupakan konsep pengabungan dua atau lebih sumber energi yang berbeda untuk memenuhi kebutuhan beban listrik yang ada, sehingga hal ini diharapkan dapat mengatasi pengunaan energi apabila supply energi listrik yang lain bermasalah. Salah satu contohnya adalah pengabungan energi surya dan energi angin. keunggulan dari pembangkit hybrid ini adalah tidak bersifat polutif, berlimpah, tidak pernah habis dan dapat dimanfaatkan secara langsung maupun tidak langsung dan merupakan energi sepanjang masa. Pada bagian pembangkit energi angin yang digunakan adalah jenis turbin angin sumbu vertikal savonius yang dimana turbin ini sangat cocok digunakan pada tipe angin kecepatan rendah yang ada di kota Palembang dengan menggunakan generator MY-1016 dengan daya keluaranya 350 Watt. Sistem pembangkit energi listrik hybrid mini menggunakan turbin angin sumbu vertikal savonius sebagai sumber energi alternatif terdiri dari beberapa komponen antara lain: Turbin angin sumbu vertikal savonius, Generator MY-1016, Kontroler, Internet of Things (IOT), Sensor anemometer, Sensor arus INA219, Sistem penyimpanan energi (baterai, pump storage), dan Inverter 1500 Watt.
\end{abstract}

Kata kunci: turbin angin sumbu vertikal savonius, generator MY-1016, sensor anemometer, sensor arus INA219, Internet Of Things, baterai, inverter 1500 Watt

Diterima Redaksi : 08-07-2021 | Selesai Revisi : 19-12-2021 | Diterbitkan Online : 31-12-2021

\section{Pendahuluan}

Dalam kondisi krisis energi listrik sekarang ini negaranegara di dunia berlomba-lomba untuk mencari dan memanfaatkan sumber energi alternatif tidak terkecuali negara berkembang seperti Indonesia [1]-[3]. Lebih dari $86 \%$ dari energi dunia saat ini berasal dari bahan bakar fosil, sementara itu permintaan kebutuhan energi di dunia terus tumbuh pesat. Sebagaimana yang kita ketahui sumber energi fosil sifatnya non-renewable (tidak dapat diperbarui) jika kita tetap bertahan menggunakan energi fosil sebagai sumber energi maka suatu saat sumber energi tersebut akan habis [2][3].
Pemerintah Indonesia menggandeng BUMN dan sektor swasta untuk menunjang program pemerintah dalam menggiatkan pembangkitan dan penggunaan energi terbarukan baik melalui energi angin [4][5] maupun energi surya [6]-[8].

Energi terbarukan selain tersedia tidak terbatas, juga memiliki dampak lingkungan yang minimal dan cenderung ramah lingkungan, hal ini dibukti oleh analisa ekonomi oleh Yudha et al. tahun 2018 [9]. Peneliti juga menggiatkan penelitian aplikasi energi terbarukan dalam kehidupan masyarakat contohnya sebagai penggerak pompa irigasi [10]-[15] maupun konsep transportasi 
energi surya dan robot tenaga surya [16][17]. Walaupun dalam pelaksanaan penggunaan energi surya ini masih memiliki keterbatasan, salah satunya sangat dipengaruhi oleh keadaan lingkungan [18]. Peneliti tetap mencari jalan untuk mengoptimalkan energi listrik yang dihasilkan oleh pembangkit energi terbarukan [19]-[24], mengingat masih terbuka lebar peluang pemanfaatan energi terbarukan, salah satunya di tambang terbuka [25]. Berdasarkan latar belakan masalah diatas perlu dicari solusi untuk menemukan sumber-sumber energi renewable (dapat diperbarui) untuk mengantikan sumber energi yang non-renewable (tidak dapat diperbarui). Energi Angin dan Energi Matahari merupakan energi yang bersifat renewble yang bersih dan tersedia secara bebas dan kedua energi tersebut dapat digabungkan menjadi Pembangkit Listrik Tenaga Hybrid (PLTH) [26][27].

Sistem Pembangkit Listrik Tenaga Hybrid (PLTH) merupakan konsep pengabungan dua atau lebih sumber energi yang berbeda untuk memenuhi kebutuhan beban listrik yang ada, sehingga hal ini diharapkan dapat mengatasi penggunaan energi apabilah supply energi listrikyang lain bermasalah..

Potensi energi angin yang dimiliki Indonesia diidentifikasi sekitar 978MW. Pada beberapa lokasi di Indonesia telah dilakukan beberapa kali penelitian dan pengukuran potensi energi angin baik oleh Lembaga pemerintahan seperti (LAPAN, BMKG). Potensi tenaga angin di darat ke kuatannya terbatas, dengan kecepatan angin rata-rata antara $3 \mathrm{~m} / \mathrm{s}-7 \mathrm{~m} / \mathrm{s}$, teknologi tubin angin skala besar dapat bekerja dengan baik pada kecepatan angin antara $5 \mathrm{~m} / \mathrm{s}-20 \mathrm{~m} / \mathrm{s}$. Jika kecepatan angin kurang dari $5 \mathrm{~m} / \mathrm{s}$ sebaiknya mengunakan turbin angin poros vertikal agar energi listrik yang dihasilkan dapat lebih efektif dan efisien. Untuk kecepatan angin di Sumatra Selatan Khususnya Kota Palembang termasuk dalam kategori kecepatan angin rendah, sehingga jika ingin membuat Pembangkit Listrik Tenaga Angin (PLTA) perlu dirancang turbin angin yang sesuai untuk kecepatan angin yang rendah agar dapat bekerja secara efektif dan efisien.

Paper ini membahas tentang pembangkit listrik energi angin yang terhubung pada sistem hybrid mini. Turbin angin yang dipakai pada penelitian ini turbin angin sumbu vertical savonius dengan simulasi SEM. Sistem turbin angin ini dilengkapi dengan sensor anomemeter, sensor arus INA219 sebagai input bagi pembangkit listrik yang di monitoring daya yang dihasilkan pembangkit listrik secara Internet of Things (IOT) dengan menggunakan aplikasi Blynk.

\section{Metode Penelitian}

\subsection{Angin}

Angin adalah udara yang bergerak akibat adanya perbedaan tekanan udara arah aliran angin dari tempat yang memiliki tekanan tinggi ke tempat yang bertekanan rendah atau dari daerah tyang memiliki suhu rendah ke wilaya bersuhu tinggi.

Angin memiliki hubungan yang erat dengan sinar matahari karena daerah yang terkena banyak paparan sinar matahari akan memiliki suhu yang lebih tinggi serta tekanan udara yang lebih renda dari daerah lain di sekitarnya akan menyebabkan aliran udara yang kencang

\subsection{Kecepatan Angin}

Secara umum dibagi menjadi beberapa kelas. Skala yang digunakan untuk mengukur kecepatan angin baik untuk didarat maupun dilaut adalah dengan skala Beaufort. Skala Beaufort dimulai dari angka 0 untuk hembusan angin paling tenang hingga angka 12 yang bersifat berbahaya dan menghancurkan

\begin{tabular}{|c|c|c|c|}
\hline \multicolumn{5}{|c}{ Tabel 1. Skala Angin Beaufort. } \\
$\begin{array}{c}\text { Nomor } \\
\text { Beaufort }\end{array}$ & $\begin{array}{c}\text { Kekuatan } \\
\text { angin }\end{array}$ & $\begin{array}{c}\text { Kecepatan } \\
\text { angin rata-rata } \\
(\mathrm{km} / \mathrm{jam})\end{array}$ & $\begin{array}{c}\text { Kecepatan } \\
\text { angin rata-rata } \\
(\mathrm{m} / \mathrm{s})\end{array}$ \\
\hline 0 & Tenang & $<1$ & $<0,277$ \\
\hline 1 & Sedikit tenang & $1-5$ & $0,27-1,3$ \\
\hline 2 & $\begin{array}{c}\text { Sedikit } \\
\text { hembusan } \\
\text { angin }\end{array}$ & $6-11$ & $1,6-3,05$ \\
\hline 3 & $\begin{array}{c}\text { Hembusan } \\
\text { angin pelan }\end{array}$ & $12-19$ & $3,33-5,27$ \\
\hline 4 & $\begin{array}{c}\text { Hembusan } \\
\text { angin sedang }\end{array}$ & $20-29$ & $5,55-8,05$ \\
\hline 5 & $\begin{array}{c}\text { Hembusan } \\
\text { angin sejuk }\end{array}$ & $30-39$ & $8,33-10,83$ \\
\hline 6 & $\begin{array}{c}\text { Hembusan } \\
\text { angin kuat }\end{array}$ & $40-50$ & $11,11-13,88$ \\
\hline 7 & $\begin{array}{c}\text { Mendekati } \\
\text { kencang }\end{array}$ & $51-61$ & $14,16-16,94$ \\
\hline 8 & Kencang & $62-74$ & $17,22-20,55$ \\
\hline 9 & $\begin{array}{c}\text { Kencang } \\
\text { sekali }\end{array}$ & $75-87$ & $20,44-24,16$ \\
\hline 10 & Badai & $88-101$ & $24,44-28,05$ \\
\hline 11 & Badai dahsyat & $102-117$ & $28,33-32,5$ \\
\hline 12 & Badai topan & $>118$ & $>32,77$ \\
\hline & & & \\
\hline
\end{tabular}

Untuk data kecepatan angin di sumatera selatan khususnya di kota Palembang penulis menggunakan data kecepatan angin rata-rata dari stasiun BMKG Sultan Mahmud Badaruddin II Palembang untuk tahun 2020 dengan cepatan angin yang dapat dilihat pada tabel 2

Tabel 2 Data Kecepatan Angin Kota Palembang tahun 2020
\begin{tabular}{|c|c|}
\hline Bulan & Kecepatan Angin rata-rata (m/s) \\
\hline Januari & 1,7 \\
\hline Februari & 1,9 \\
\hline Maret & 1,6 \\
\hline April & 1,1 \\
\hline Mei & 1,4 \\
\hline Juni & 1,6 \\
\hline Juli & 1,5 \\
\hline Agustus & 2,8 \\
\hline September & 2,8 \\
\hline Oktober & 1,9 \\
\hline November & 1,7 \\
\hline Desember & 2,2 \\
\hline
\end{tabular}

\subsection{Pembangkit Listrik Tenaga Angin (PLTAngin)}

PLTAngin adalah suatu pembangkit listrik yang menggunakan angin sebagai sumber energi untuk menghasilkanenergi listrik.

PLTAngin memiliki 3 komponen utama yaitu, Angin, merupakan komponen pertama untuk menggerakan turbin angin, Turbin Angin, Komponen yang digunakan untuk mengubah energi kinetic dari angin menjadi energi 
mekanik oleh turbin, Generator, memiliki peranan penting pada PLTAngin untuk mengubah energi mekanik yang dihasilkan tubin menjadi energi listrik.

Untuk jenis turbin angin yang digunakan pada pembangkit energi listrik hybrid mini menggunakan turbin angin sumbu vertikal savonius sebagai sumber energi alternatif yang dimana turbin angin sumbu vertikal savonius ini sangat efektif dan efesien jika digunakan pada skala kecepatan angin rendah.

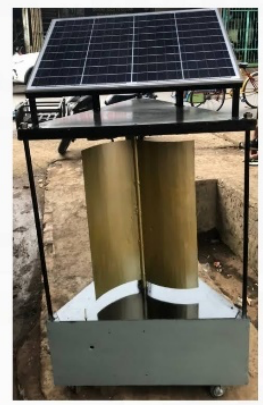

Gambar 1. Turbin Angin Savonius

\subsection{Generator Magnet Permanen}

Generator magnet permanen merupakan generator sinkron yang medan magnet dihasilkan oleh magnet permanen bukan dari kumparan sehingga fluks magnetic yang dihasilkan oleh medan magnet permanen. Generator magnet permanen biasanya digunakan pada pembangkit listrik untuk mengubah energi mekanik dari turbin menjadi energi listrik. Dalam generator magnet permanen, medan magnet rotor dihasilkan oleh magnet permanen sihingga tidak memerlukan arus DC untuk membangkitkan medan magnet.

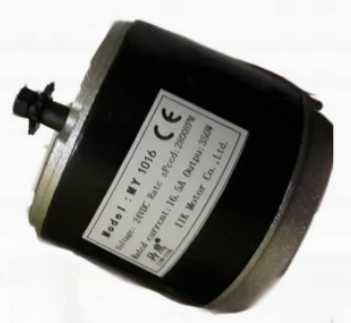

Gambar 2. Generator magnet permanen fluks aksial

\subsection{Baterai}

Akumulator (accu, aki) adalah sebuah alat yang dapat menyimpan energi dalam bentuk energi kimia. Untuk pemilihan baterai sebagai pemasok dari turbin menggunakan persamaan:

$\mathrm{P}_{\mathrm{B}}=$ Jumlah beban perhari X 2 ....

$\mathrm{P}_{\mathrm{B}} /$ volt/amp $=$ buah baterai

Ket :

$\mathrm{P}_{\mathrm{B}}=$ Kapasitas baterai

\subsection{Inverter}

Inverter adalah suatu rangkaian elektronika daya yang digunakan searah (DC) menjadi tegangan bolak-balik (AC). Untuk menentukan kapasitas inverter yang akan digunakan pada beban dengan cara menjumlahkan semua daya pada beban pada penelitian ini penulis menggunakan inverter dengan kapasitas maksimal 1500Watt.

\subsection{Sistem Konversi Energi Angin Menjadi Energi Listrik.}

Energi mekanik pada turbin angin diperoleh dari suatu proses konversi energi angin. Energi angin sendiri merupakan energi yang berasal dari pergerakan massa udara yang bergerak dari suatu daerah bertekanan maksimum ke daerah bertekanan minimum. Massa udara yang bergerak ini disebut sebagai energi kinetik karena memiliki kecepatan gerak, sehingga daya yang menjadi input turbin angin tak lain berasal dari energi kinetik angin. Besarnya daya tersebut secara matematis dapat dituliskan sebagai berikut [4].

$P_{t o t}=m \frac{v i^{2}}{2 g c}$

Sedangkan $: m=p A V i$

Maka : $\mathrm{P}=$

$\frac{1}{2 g c} p A V i^{3}$.

\section{Keterangan}

$P_{\text {tot }} \quad$ : Daya total (Watt)

$m \quad$ : Laju aliran massa $(\mathrm{kg} / \mathrm{s})$

vi : Kecepatan datang angin $(\mathrm{m} / \mathrm{s})$

gc : Faktor konversi $1.0 \mathrm{Kg}\left(\mathrm{N} . \mathrm{s}^{2}\right)$

$\mathrm{P} \quad$ : Massa jenis udara $\left(\mathrm{kg} / \mathrm{m}^{3}\right)$

A : Area sapuan turbin $\left(\mathrm{m}^{2}\right)$

Persamaan diatas dapat digunakan untuk menghitung jumlah daya yang menjadi masukan atau input bagi turbin angin. Hasil perhitungan daya dari rumus tersebut belum dapat dijadikan acuan dalam menetapkan kapasitas daya input turbin bagi generator, sebab belum mempertimbangkan rugi-rugi daya dan faktor lain. Oleh karena itu diperlukan suatu faktor pengali yang biasa disebut sebagai faktor efisiensi. Seorang Ilmuwan Fisika dari Jerman bernama Albert Betz pada tahun 1919 menyatakan bahwa tidak ada turbin angin yang dapat mengkonversi energi kinetik angin menjadi energi mekanik (putaran) lebih dari 16/27 (59,3\%). Dikalangan peneliti dan pengembang turbin angin hal ini dikenal sebagai Batas Betz ( Betz Limits) dan membulatkan faktor tersebut menjadi $60 \%$ yang artinya tidak ada turbin angin yang dapat mengkonversi energi kinetik angin menjadi energi putaran lebih dari $60 \%$.

Berbagai faktor teknis yang menyangkut masalah pembuatan turbin angin juga mempengaruhi efisiensi turbin angin, bahkan nilainya dibawah batas Betz yaitu dalam kisaran 0.35-0.45 (35\%-45\%). Sehingga secara matematis daya aktual atau daya nyata yang dihasilkan oleh turbin angin adalah sebagai berikut :

$P m t=\varphi t \frac{1}{2 g c} p \cdot A \cdot V^{3}$ 
Keterangan

Pmt : Daya mekanik turbin (W)

$\varphi t \quad$ : Efisiensi turbin angin

\subsection{Mikrokontroller}

Mikrokontroler adalah sebuah sistem komputer yang seluruh atau sebagian besar elemennya dikemas dalam satu chip IC, sehingga sering disebut dengan single chip mikrokomputer.

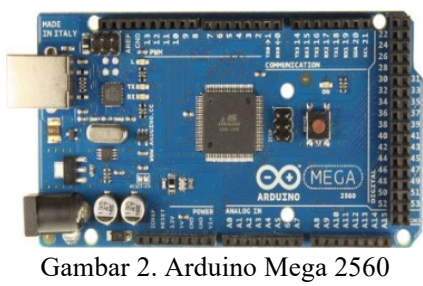

Arduino Mega 2560 adalah board mikrokontroler yang berbasis pada ATmega2560. Memiliki 54 pin input / output digital, 16 input analog, 4 UART (port serial perangkat keras), osilator kristal $16 \mathrm{MHz}$, koneksi USB, header ICSP, dan tombol reset. Berisi semua yang dibutuhkan untuk mendukung mikrokontroler. [5]

\subsection{Sensor Arus INA219}

Sensor arus yang digunakan berupa modul sensor arus INA219 yang memiliki kegunaan untuk mendeteksi besar arus yang mengalir lewat blok terminal [6].

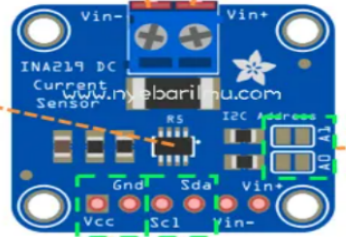

Gambar 3. Sensor Arus INA219

INA219 merupakan modul sensor yang dapat memonitoring tegangan dan arus pada suatu rangkaian listrik. INA 219 didukung dengan interface I2C atau SMBUS-COMPATIBLE dimana peralatan ini mampu memonitoring tegangan shunt dan suplai tegangan bus, dengan konversi program times dan filtering. [7].

INA 219 memiliki sebuah amplifier input maksimum adalah $\pm 320 \mathrm{mV}$ ini berarti dapat mengukur arus hingga $\pm 3,2 \mathrm{~A}$. Dengan internal data 12 bit ADC, resulusi pada kisaran 3.2A adalah $0,8 \mathrm{~mA}$.

\subsection{Sensor Anemometer}

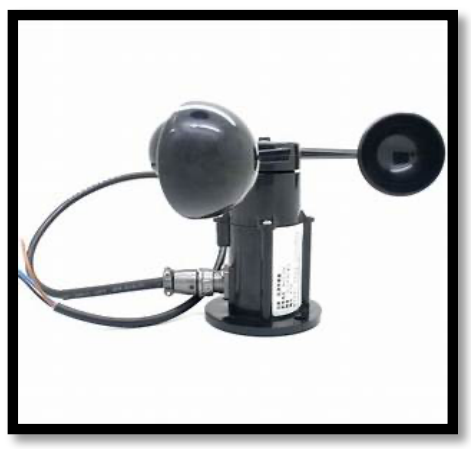

Gambar 5. Sensor Anemometer

Anemometer secara umum yaitu sebuah alat yang digunakan untuk mengukur arah dan tingkat kecepatan angin. Alat ini menjadi alat utama dan sangat dibutuhkan oleh lembaga / badan meteorologi, klimatologi dan geofisika / BMKG [8].

Fungsi dari anemometer cukup terbatas dan bukan termasuk ke dalam alat yang cukup multifungsi. Fungsinya pun hanya sebatas akan hal yang berhubungan dengan angin dan cuaca. Inilah fungsi dari alat anemometer anatara lain seperti,ntuk mengukur tingkat kecepatan angin, Dapat digunakan sebagai alat dalam melamar / memperkirakan cuaca pada hari berikutnya, Untuk memperkirakan tinggi / besarnya gelombang laut, Fungsi dari anemometer yang satu ini dipergunakan oleh para nelayan dan orang yang bekerja di kapal, baik kapal pesiar / kapal biasa dan untuk mengetahui besarnya tekanan angin

\subsection{Internet Of Things ( IOT )}

Internet of Things atau dikenal juga dengan singkatan IoT, merupakan sebuah konsep yang bertujuan untuk memperluas manfaat dari konektivitas internet yang tersambung secara terusmenerus yang memungkinkan kita untuk menghubungkan mesin, peralatan, dan benda fisik lainnya dengan sensor jaringan dan aktuator untuk memperoleh data dan mengelola kinerjanya sendiri, sehingga memungkinkan mesin untuk berkolaborasi dan bahkan bertindak berdasarkan informasi baru yang diperoleh secara independen. Internet of Things akan digunakan untuk memonitoring berapa daya yang dihasilkan pada pembangkit energi listrik hybrid dengan menggunakan aplikasi Blynk [9]

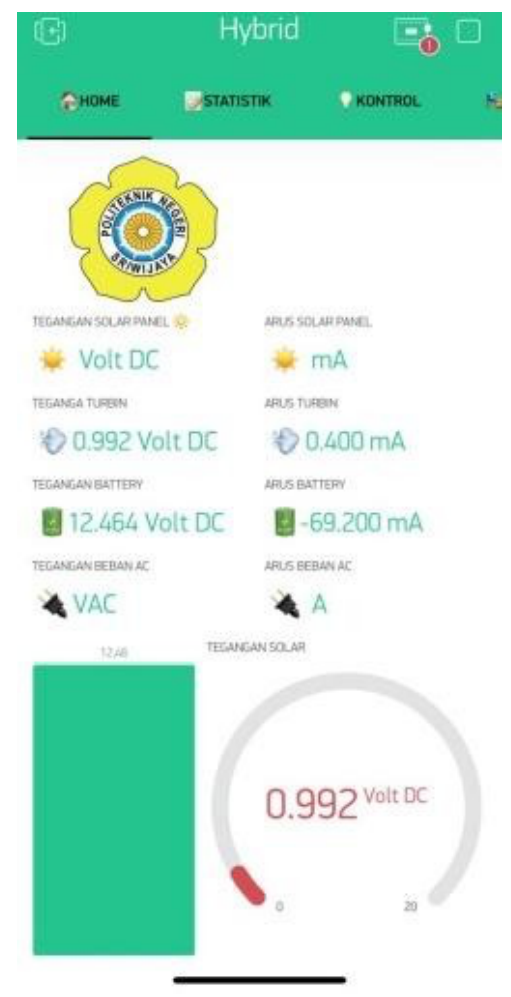




\section{Gambar 6 Internet Of Things}

2.11. Blok Diagram sistem software

Adapun pada Gambar 6. merupakan blok diagram dari perancangan Pembangkit energi listrik hybrid menggunakan energi angin dan surya.

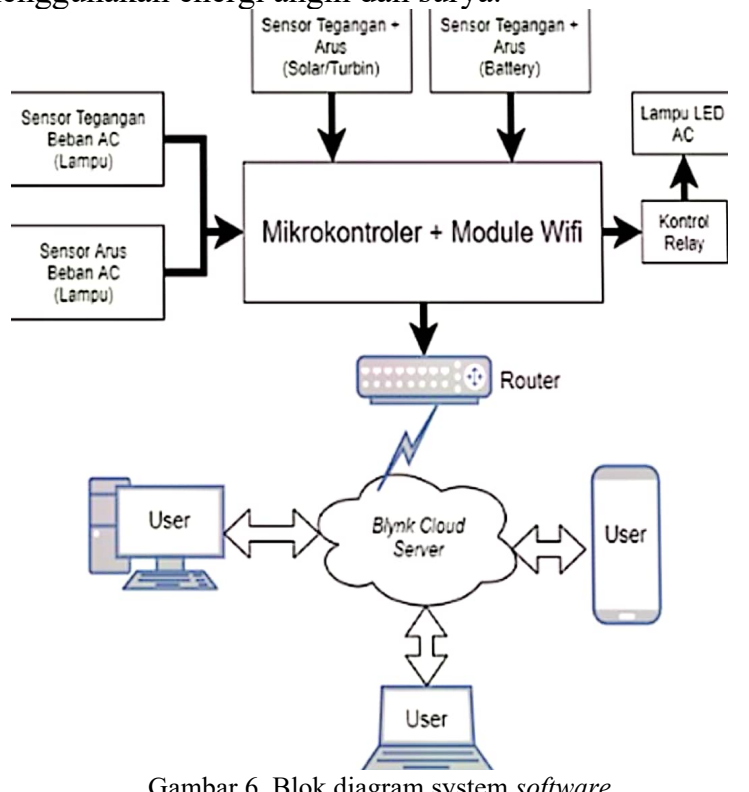

Pada rangakaian monitoring Hybrid menggunakan mikrokontroler Arduino Mega berbasis wifi sehingga memungkinkan perangkat yang akan dirancang dapat terkoneksi ke internet, rangkaian monitoring ini juga menggunakan Sensor INA219 sebagai pembacaan Tegangan dan Arus dari Solar/Turbin dan Battery, Selain itu jg rangkaian ini juga dipasang sensor tegangan dan arus AC untuk mengukur tegangan dan arus beban pada saat beban aktif, beban pada rangkaian ini menggunakan Lampu LED AC yang mana terhubung pada module relay sehingga lampu dapat dihidup dan matikan menggunakan smartphone melalui aplikasi yang telah dirancang.

Proses pengiriman data dari perangkat monitoring menggunakan server blynk sehingga aplikasi dapat mengakses semua data secara online dan realtime. Aplikasi yang telah dirancang dapat digunakan pada smartphone tipe android maupun ios serta dapat diinstall pada laptop maupun komputer.

\subsection{Flowchart Rangkaian}

Ketika perangkat diaktifkan seluruh sensor akan melakukan inisialisasi agar dapat diakses oleh mikrokontroler, selanjutnya mikrokontroler mencari koneksi internet dan setelah terkoneksi, seluruh data hasil pembacaan dikirimkan ke server blynk agar dapat ditampilkan ke aplikasi yang telah kita rancang, apabila hasil pembacaan tengan dan sensor terdapat anomali (tidak normal) maka akan muncul notifikasi pada aplikasi bahwa terdapat tegangan dan arus yang tidak normal sesuai dengan settingan yang diinput pada mikrokontroller yang kita gunakan.

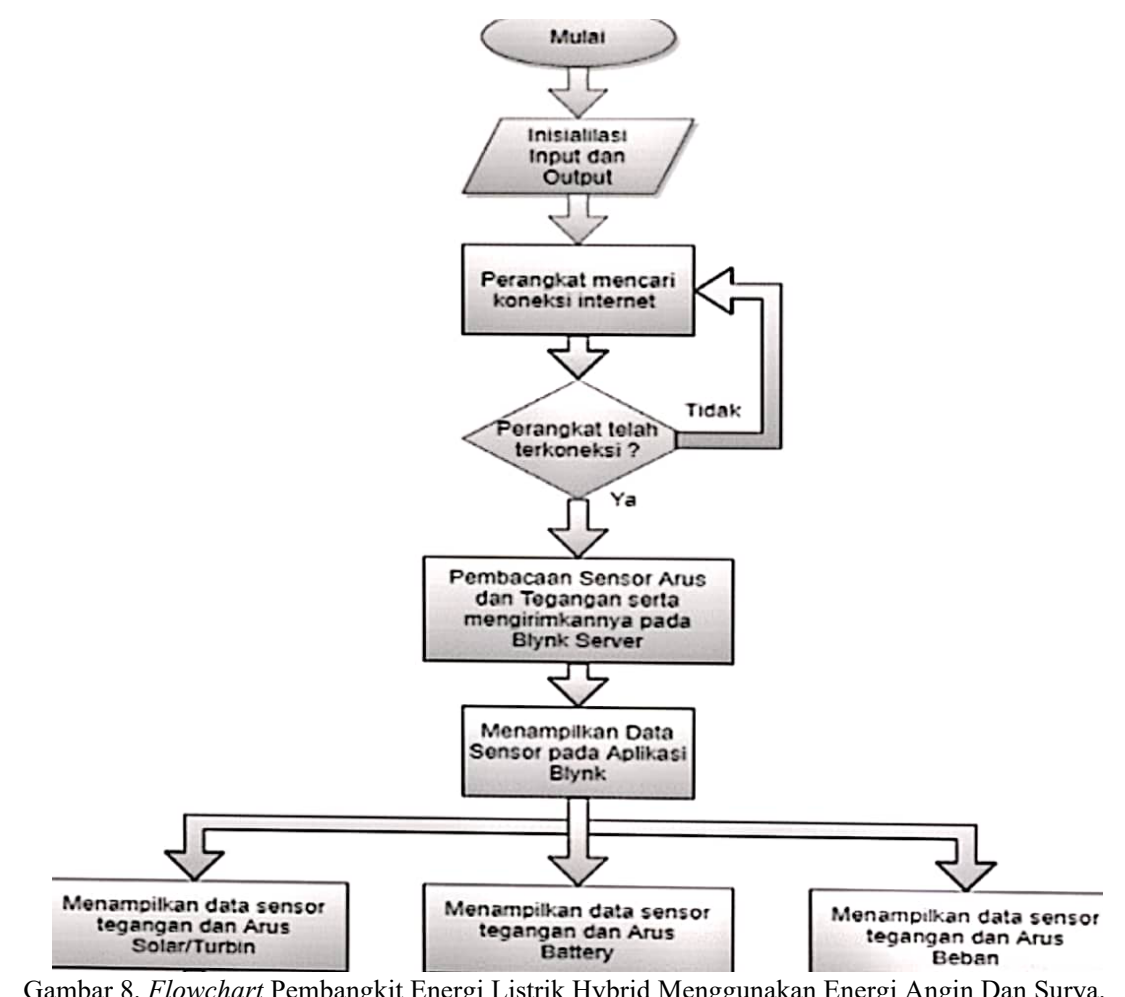

\section{Hasil dan Pembahasan} Dalam penc 3.1 System Advisor Model (SAM) System Advisor Model (SAM) adalah model kinerja dan keputusan bagi orang-orang yang terlibat dalam industri keuangan yang dirancang untuk memperkirakan biaya energi untuk proyek pembangkit listrik yang terhubung ke jaringan berdasarkan biaya pemasangan dan pengoperasian
serta desain sistem untuk memfasilitasi pengambilan 
energi terbarukan.

Pada Gambar 9 merupakan awal dari karakteristik desain turbin pada System Advisor Model (SAM). Terlihat generator yang digunakan adalah generator dengan output maksimal 0,38 kw atau 350Watt dengan diameter $70 \mathrm{~m}$ jenis turbin angin savonius yang sangat efektif dan efesien untuk kecepan angin rendah pada Kota Palembang Indonesia ,
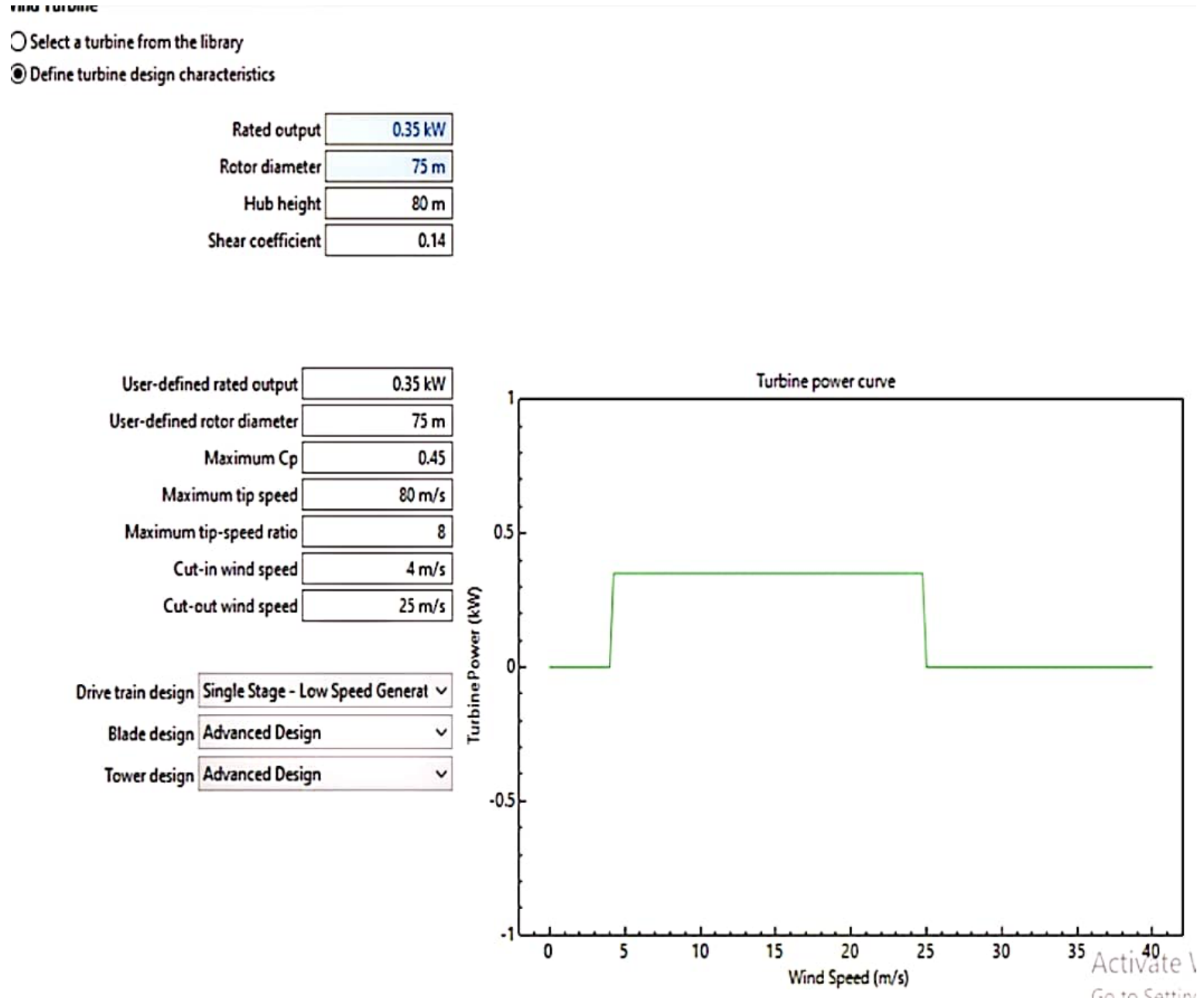

Gambar 9 Data Awal Pada Turbin Angin

Pada Gambar 10 merupakan kondisi dimana turbin angin beroperasi selama 1 tahun dengan generator daya output maksimal 350Watt maka daya yang dihasilkan sangat maksimus hal ini dapat dijelaskan pada grafik gambar 10 yang dimana setiap tahun nya daya yang dihasilkan sangat sedikit kerugian nya..

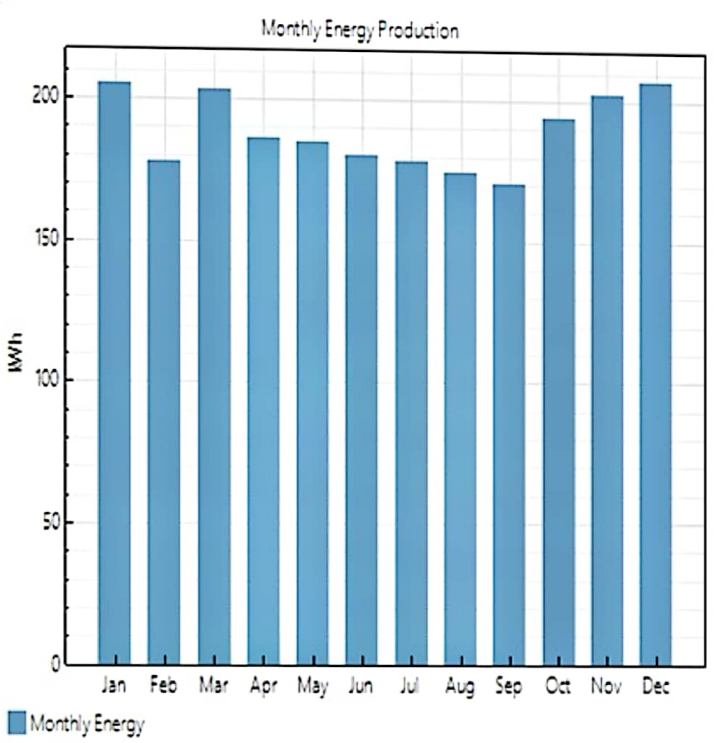

Gambar 10 Grafik daya yang dihasikan turbin selama 1 tahun beroperasi 
Pada Gambar 11 dapat kita lihat keuntungan dan kerugian jika kita menggunakan turbin angin jenis savonius dengan generator yang memiliki output maksimal 350Watt.

\begin{tabular}{|ll|}
\hline Metric & Value \\
\hline Annual energy (year 1) & $2,266 \mathrm{kWh}$ \\
\hline Capacity & $0 \mathrm{~kW}$ \\
\hline Capacity factor (year 1) & $73.9 \%$ \\
\hline PPA price (year 1) & $1000.00 \mathrm{c/kWh}$ \\
PPA price escalation & $1.00 \% / \mathrm{year}$ \\
Levelized PPA price (nominal) & $1072.23 \mathrm{c} / \mathrm{kWh}$ \\
Levelized PPA price (real) & $851.32 \mathrm{c} / \mathrm{kWh}$ \\
\hline Levelized COE (nominal) & $1736.27 \mathrm{c} / \mathrm{kWh}$ \\
\hline Levelized COE (real) & $1378.55 \mathrm{c} / \mathrm{kWh}$ \\
Net present value & $\$-147,087$ \\
Internal rate of return (IRR) & $\mathrm{NaN}$ \\
Year IRR is achieved & $\mathrm{NaN}$ \\
\hline IRR at end of project & $0.53 \%$ \\
Net capital cost & $\$ 464,212$ \\
Equity & $\$ 278,623$ \\
Size of debt & $\$ 185,590$ \\
\hline
\end{tabular}

Gambar 11 Data Akhir Dari Turbin Angin

\section{Kesimpulan}

Dari penelitian yang telah dilakukan, Pembangkit energi listrik hybrid mini menggunakan turbin angin sumbu vertical savonius sebagai sumber energi alternatif dengan menggunakan generator daya output maksimal 350Watt sangat efektif dan efisien jika di lakukan di tempat kecepatan angin rendah bisa dilihat dari hasil data yang peneleti dapatkan menggunakan software SAM yang dimana energi listrik yang didapatkan untuk 1 tahun nya mencapai 2,266kWh dan keuntungan lain nya adalah dengan menggunakan Pembangkit energi listrik hybrid mini menggunakan turbin angin sumbu vertikal savonius sebagai sumber energi alternatif adalah energi yang digunakan bersifat rewnewable (dapat diperbarui) sehingga mengurangi penyebab terjadinya polusi udara yang dihasilkan oleh pembangkit listrik yang bersifat irenewable (tidak dapat diperbarui)

\section{Daftar Rujukan}

1. Muhammad AS Hikam, Ketahanan energi indonesia tantangan dan harapan. 2015.

2. IRENA, Renewable Energy Prospects: Indonesia, a REmap analysis, International Renewable Energy Agency (IRENA), Abu Dhabi, 2017, www.irena.org/remap.

3. DEN, "Outlook Energy Indonesia 2019," Secretariat General National Energy Council, ISSN 2527-3000.

4. Wardhana. A. T., Taqwa. A. and Dewi. T., "Design of Mini Horizontal Wind Turbine for Low Wind Speed Area," In Proceeding of Journal of Physics: Conference Series 347(1), p. $01202,2019$.

5. Yuliandi. R. B., Dewi. T., and Rusdianasari, "Comparison of Blade Dimension Design of a Vertical Wind Turbine Applied in Low Wind Speed," In proceeding of E3S Web of Conferences EDP Sciences, 68, p. 01001, 2018.

6. Edward. A, Dewi. T, and Rusdianasari, 2019, "The effectiveness of Solar Tracker Use on Solar Panels to The Output of The Generated Electricity Power IOP Conference Series," in
Proceeding of Earth and Environmental Science, 347(1), p. 012130.

7. Hamdi. BRD. M, Dewi. T, and Rusdianasari, 2019. "Performance Comparison of 3 Kwp Solar Panels Between Fixed and Sun Tracking in Palembang-Indonesia," In Proceeding of IOP Conference Series: Earth and Environmental Science, 347(1). p. 012131,

8. Zhafarina. I. N, Dewi. T, and Rusdianasari, 2018. "Analysis of Maximum Power Reduction Efficiency of Photovoltaic System at PT. Pertamina (Persero) RU III Plaju," VOLT: Jurnal Ilmiah Pendidikan Teknik Elektro, 3(1), pp.19-25.

9. Yudha. H. M., Dewi. T., Risma. P., and Oktarina. Y., "Life Cycle Analysis for the Feasibility of Photovoltaic System Application in Indonesia," in Proceeding International Conference on Science, Infrastructure Technology and Regional Development (ICoSITeR) 2017 "Energy Security for Enhancing National Competitiveness" 25-26 August 2017, South Lampung, Indonesia, IOP Conference Series: Earth and Environmental Science 124 012005, 2018. doi :10.1088/1755-1315/124/1/012005.

10. Putra. P. P, Dewi. T, Rusdianasari, "MPPT Implementation for Solar-powered Watering System Performance Enhancement," Technology Reports of Kansai University, 63(1), pp. 6919-6931, 2021. ISSN: 04532198.

11. Eshra. N . G, and Salem. M. G, 2020 "Solar Energy Application in Drainage Pumping Stations to Save Water and Reducing CO2 Emission," Energy Reports, Vol. 6, Supplement 6, pp. 354-366, https://doi.org/10.1016/j.egyr.2020.08.056.

12. Imjai.T ,Thinsurat. K, Ditthakit. P, Wipulanusat. W, Setkit. M, and Garcia. R, 2020. "Performance Study of an Integrated Solar Water Supply System for Isolated Agricultural Areas in Thailand: A CaseStudy of the Royal Initiative Project," Water, Vol. 12, p. 2438

13. Korpale. V. S, Kokate. D. H, and Deshmukh. S. P, 2016. "Performance Assessment of Solar Agricultural Water Pumping System," Energy Procedia, Vol. 90, pp. 518-524. https://doi.org/10.1016/j.egypro.2016.11.219.

14. Elrefai. M, Hamdy. R. A, ElZawawi. A, and Hamad. M. S, 2016. "Design and Performance Evaluation of a Solar Water Pumping System: a Case Study," 2016 Eighteenth International Middle East Power Systems Conference (MEPCON), Cairo. pp. 914-920, doi: 10.1109/MEPCON.2016.7837005.

15. Aroudam. A. BA. A, Chighali. O. E, Hamdoun. O, and Mohamed. M. L, 2018 "Performance Optimization of the PV Pumping System," presented in 11th International Conference Interdisciplinarity in Engineering, INTER-ENG 2017, 5-6 October 2017, Tirgu-Mures, Romania, Procedia Manufacturing, Vol. 22, pp. 788-795, https://doi.org/10.1016/i.promfg.2018.03.112

16. Dewi. T, Risma. P, Oktarina. Y, Roseno. M. T, Yudha,. M. H. Handayani. A. S, and Wijanarko. Y, 2016"A Survey on Solar Cell; The Role of Solar Cell in Robotics and Robotic Application in Solar Cell industry," in Proceeding Forum in Research, Science, and Technology (FIRST), r Retrieved from http://eprints.polsri.ac.id/3576/3/C4.pdf.

17. Dewi. T, Risma. P, Oktarina. Y, Taqwa. A, Rusdiansari, and Renaldi. H. "Experimental Analysis on Solar Powered Mobile Robot as the Prototype for Environmentally Friendly Automated Transportation," presented in International Conference on Applied Science and Technology (iCAST on Engineering Science) Bali, Indonesia, of Physics: Conference Series, Vol. 1450.

18. Dewi. T, Risma. P, and Oktarina. Y, 2018,2019, "A Review of Factors Affecting the Efficiency and Output of a PV system Applied in Tropical Climate," in IOP Conference Series: Earth and Environmental Science 258012039 ICoSITer. doi:10.1088/17551315/258/1/012039.

19. Sarwono, Dewi. T, and RD Kusumanto, "Geographical Location Effects on PV Panel Output - Comparison Between Highland and Lowland Installation in South Sumatra, Indonesia," Technology Reports of Kansai University, 63(02), pp. 7229-7243, 2021. ISSN: 04532198.

20. Sasmanto. A. A., Dewi. T., and Rusdianasari, "Eligibility Study on Floating Solar Panel Installation over Brackish Water in Sungsang, South Sumatra," EMITTER International Journal of Engineering Technology, 8(1), 2020.

21. Junianto. B., Dewi. T., and Sitompul. C. R.,"Development and Feasibility Analysis of Floating Solar Panel Application in Palembang, South Sumatra Journal of Physics: Conf. Series 3nd Forum in Research, Science, and Technology Palembang, Indonesia, 2020.

22. Arissetyadhi. I., Dewi. T., and RD Kusumanto, "Experimental Study on The Effect of Arches Setting on Semi-Flexible Monocrystalline 
Edo Triyandi ${ }^{1}$, Pola Risma ${ }^{2}$, RD. Kusumanto ${ }^{3}$, Tresna Dewi ${ }^{4}$, Yurni Oktarini ${ }^{5}$ Journal of Applied Smart Electrical Network and System (JASENS) Vol. 2 No. 2 (2021) 49 - 56

Solar Panels, "Kinetik: Game Technology, Information System, , Computer Network, Computing, Electronics, and Control. KINETIK 5(2), pp. 111-118, 2020.

23. Harahap. H. A., Dewi. T., and Rusdianasari, "Automatic Cooling System for Efficiency and Output Enhancement of a PV System Application in Palembang, Indonesia," in 2nd Forum in Research, Science, and Technology, IOP Conf. Series: Journal of Physics: Conf. Series 1167012027 , 2019. doi:10.1088/1742$6596 / 1167 / 1 / 012027$.

24. Setiawan. F., Dewi. T., and Yusi. S., "Sea Salt Deposition Effect on Output and Efficiency Losses of the Photovoltaic System; a case study in Palembang, Indonesia," in Proceeding of Journal of Physics: Conf., 1167, p 012027, 2019.

25. Junaedi. K, Dewi. T, and Yusi. M. S, 2021 "The Potential Overview of PV System Installation at the Quarry Open Pit Mine PT. Bukit Asam, Tbk Tanjung Enim," Kinetik: Game Technology, Information System, Computer Network, Computing, Electronics, and Control, 5(1), pp. 41-50, https://doi.org/10.22219/kinetik.v6i1.1148.

26. Hanafiah. B., Taqwa. A., RD Kusumanto, and Dewi. T., "Synchronization and Application of IoT for on Grid Hybrid PVWind System," In Proceeding of 2018 International Conference on Applied Science and Technology (iCAST) IEEE, p. 617-621, 2018.

27. H. Harmini and T. Nurhayati, "Pemodelan Sistem Pembangkit Hybrid Energi Solar Dan Angin,” Elektrika, vol. 10, no. 2, p. 28, 2018, doi: 10.26623/elektrika.v10i2.1167 